$\mathrm{BNL}-64570$

Informal Report

\title{
REPORT ON INTERCOMPARISONS OF CONDENSATION NUCLEUS COUNTER MEASUREMENTS DURING THE ACE-1 INTENSIVE STUDY
}

\author{
R. J. Weber \\ Brookhaven National Laboratory \\ Environmental Chemistry Division \\ Department of Applied Science \\ Upton, NY 11973-5000
}

June 1997

\section{DISCLAIMER}

This report was prepared as an account of work sponsored by an agency of the United States Government. Neither the United States Government nor any agency thereof, nor any of their employees, makes any warranty, express or implied, or assumes any legal liability or responsibility for the accuracy, completeness, or usefulness of any information, apparatus, product, or process disclosed, or represents that its use would not infringe privately owned rights. Reference herein to any specific commercial product, process, or service by trade name, trademark, manufacturer, or otherwise does not necessarily constitute or imply its endorsement, recommendation, or favoring by the United States Government or any agency thereof. The views and opinions of authors expressed herein do not necessarily state or reflect those of the United States Government or any agency thereof. 


\section{DISCLAMIER}

Portions of this docoment may be illegible in electronic image products. Images are produced from the best available original documert. 


\begin{abstract}
This report summarizes findings from intercomparisons of aerosol particle concentrations measured by condensation nucleus counters (CNC's) on various platforms and ground-based stations during the Southern Hemisphere Marine Aerosol Characterization Experiment (ACE-1). Five CNC's on the NCAR C-130 are intercompared. The C-130 CNC's are then intercompared to ship and ground-based measurements during periods of C-130 overflights.
\end{abstract}




\section{Intercomparison of $\mathbf{C - 1 3 0} \mathbf{C N C}$ 's}

Five flights where aerosol particle concentrations spanned the range of conditions encountered during ACE-1 were used for the $\mathrm{C}-130 \mathrm{CNC}$ intercomparison. The flights considered for this study were, 16,17,21,22 and 27. All were part of the ACE-1 intensive based at Hobart, Tasmania. The data were carefully screened in an attempt to remove all anomalous particle concentrations from shatter of water droplets at sampling inlets. The five CNC's included in the C-130 intercomparison include two UCNC's, a TSI 3025 and the prototype of this instrument, the PHA UCNC, two TSI model $3010 \mathrm{CNC}$ 's, and a TSI $3760 \mathrm{CNC}$. All concentrations reported here are at the altitude of the measurement. The particle sizedependent counting efficiencies of the various CNC's were measured prior to the ACE-1 study and the results reported by Wiedensohler et al. [1977]. The various CNC"s, acronyms and counting efficiencies are given in Appendix A. All C-130 CNC's, except the RAF 3076, sampled from the community aerosol inlet.

Time Series Plots. Figure 1 shows the time series plot for a period of "clean" conditions during Flight 22. Figure 1a compares the PHA UCNC and the UH 3025 UCNC. Figure 1b compares the other three CNC's; UH 3010, RAF 3760, and DRI 3010. The UCNC's are in good agreement. The other three CNC's track well but the concentrations are offset. Figure $2 a$ and $2 b$ show the same comparisons but for a period of high particle concentrations. These measurements were made in a region of cloud venting where concentrations of nanoparticles ( 3 to $10 \mathrm{~nm}$ diameter) were also high. In this case, during periods of high concentrations, the PHA UCNC tended to be higher than the UH 3025 UCNC. Figure $2 b$ again shows some evidence of an offset between the other three CNC's.

Correlation Coefficients: Tables 1 and 2 give the correlation coefficients (Pearson Product Moment Coefficient of Correlation) for the five CNC's on the C-130 for flights 16, 17, 21, 22, and 27. Table 1 is for all data and Table 2 for a period when practically no nanoparticles were present. Periods of zero or low nanoparticle concentrations were determined from the PHA UCNC measurements of nominally 3 to $4 \mathrm{~nm}$ diameter particle concentrations, referred to here as $\tilde{\mathbf{N}}(3-4 \mathrm{~nm})$. This measurement was used due to it's high sensitivity for measuring nanoparticles. Table 2 includes only periods when $\tilde{\mathrm{N}}(3-4 \mathrm{~nm})$ was less than $0.1 \mathrm{~cm}^{-3}$. Generally, the CNC's were better correlated when few nanoparticles were present. At these times, differences in CNC lower detection limits would not influence the measurements. Note that in both tables the best correlation was between the two University of Hawaii (UH) instruments. These CNC's sampled from the same line suggesting that much of the scatter in the measurements was due to sampling differences. 



Figure 1: Comparison of $\mathrm{C}-130 \mathrm{CNC}$ measurements during a period of relatively low particle conditions. 

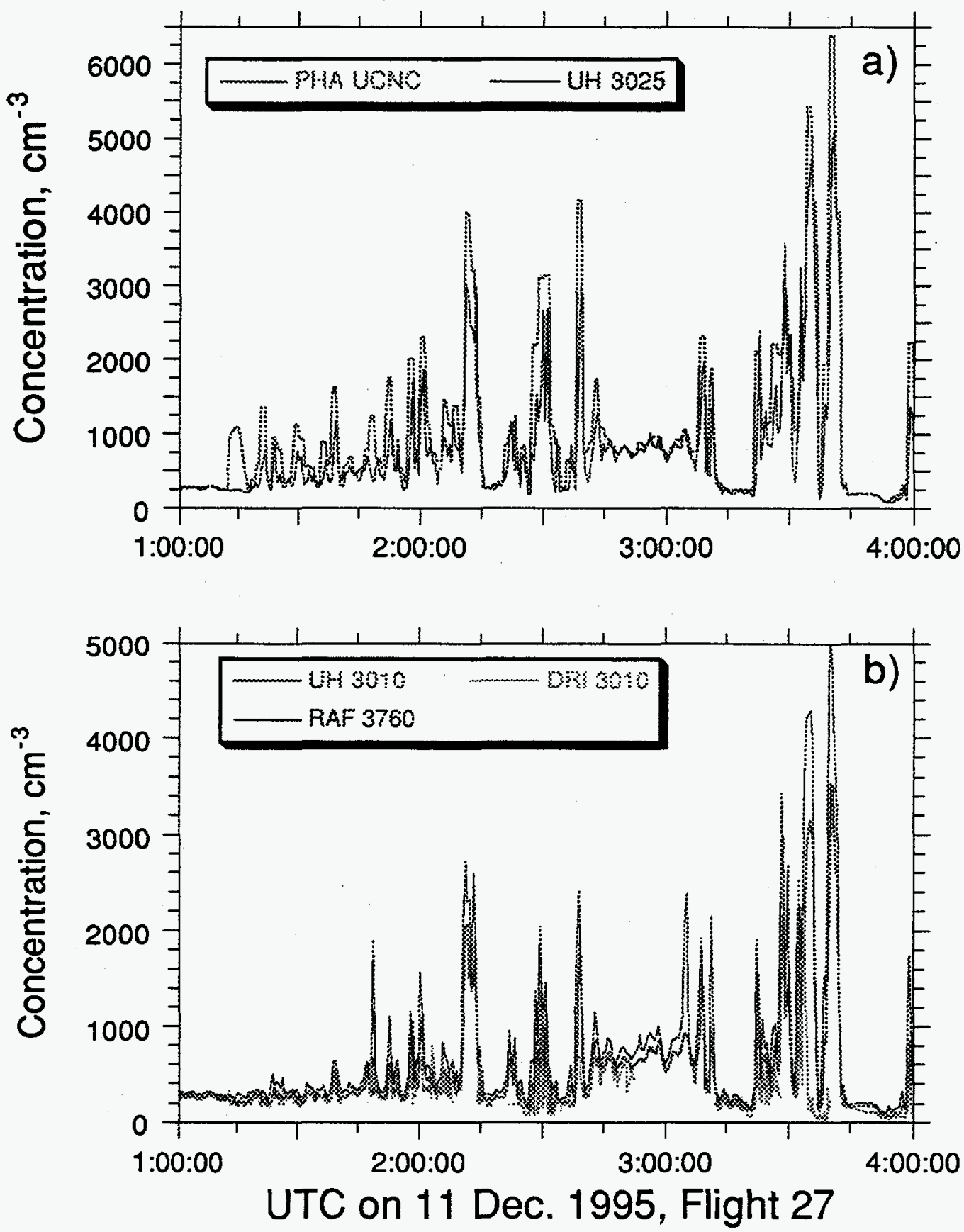

Figure 2: Comparison of C-130 CNC measurements made in regions of cloud venting. These were regions of high total particle and nanoparticle $(3-10 \mathrm{~nm})$ concentrations. 
Table 1: Correlation Coefficients For All Data for Flights 16, 17, 21, 22, 27

\begin{tabular}{llllll}
\hline & PHA UCNC & UH 3025 & RAF 3760 & UH 3010 & DRI 3010 \\
\hline PHA UCNC & 1 & & & & \\
UH 3025 & 0.873 & 1 & & & \\
RAF 3760 & 0.854 & 0.893 & 1 & & \\
UH 3010 & 0.807 & 0.927 & 0.894 & 1 & \\
DRI 3010 & 0.285 & 0.372 & 0.369 & 0.482 & 1 \\
\hline
\end{tabular}

Table 2: Correlation Coefficients For $\tilde{\mathrm{N}}(3-4 \mathrm{~nm})<0.1 \mathrm{~cm}^{-3}$ for Flights $16,17,21,22,27$

\begin{tabular}{llllll}
\hline & PHA UCNC & UH 3025 & RAF 3076 & UH 3010 & DRI 3010 \\
\hline PHA UCNC & 1 & & & & \\
UH 3025 & 0.911 & 1 & & & \\
RAF 3760 & 0.928 & 0.935 & 1 & & \\
UH 3010 & 0.903 & 0.995 & 0.931 & 1 & \\
DRI 3010 & 0.874 & 0.899 & 0.887 & 0.897 & 1 \\
\hline
\end{tabular}

Distributions of Measurements for C-130 CNC's: In this analysis the distributions of CNC measurements for Flights $16,17,21,22$, and 27 were analyzed for three different conditions: all data, periods of low nanoparticle concentrations and periods of high nanoparticle concentrations. Figure 3 shows the percentile plots for the various $\mathrm{CNC}^{\prime}$ s for all data. For each $\mathrm{CNC}$, the bottom and top of the box represent $5 \%$ and $95 \%$ of the measured concentrations. The middle dotted line is the median particle concentration (the value is also given) and the lower and upper dotted lines show the range from $25 \%$ to $75 \%$ of the data. Figure 4 is a percentile plot for low nanoparticle concentrations $\left(\tilde{\mathrm{N}}(3-4 \mathrm{~nm})<0.1 \mathrm{~cm}^{-3}\right)$ and Figure 5 are periods when the University of Hawaii CNC's indicated that the number of particles between 3 and $10 \mathrm{~nm}$ were larger than the total CN (Dp>10 nm) concentration, (i.e., UH: $\left\{\mathrm{N}_{3025}-\mathrm{N}_{3010}\right\} / \mathrm{N}_{3010}>1$ ).

Figures 3 and 4 show that the PHA UCNC, the UH 3025 UCNC, and the RAF 3760 CNC were in good agreement, particularly when few nanoparticles were present. During periods when nanoparticle concentrations were higher than those of particles larger than $10 \mathrm{~nm}$, due to higher nanoparticle counting efficiencies, Figure 5 shows that both the PHA UCNC and the UH 3025 UCNC recorded higher concentrations than the other three. Also during these periods of high nanoparticle concentrations, the PHA UCNC recorded the highest concentrations. This was also observed in Figure 2a. Since Wiedensohler et al. [1997] found that the size-dependent counting efficiencies of these two instruments were similar the cause for this difference may be due to higher sampling and transport losses of nanoparticles for the UH $3025 \mathrm{UCNC}$. Differences in nanoparticle losses could include differences in where the two instruments extracted sample air from the community aerosol inlet and differences in losses within individual sampling lines from the community aerosol inlet to the CNC's.

As observed in the time series plots, Figures 3,4 and 5 show that the UH 3010 and the DRI 3010 both tended to have a systematic offset relative to the other three CNC's. This was observed for all the ranges of concentrations studied, suggesting that the differences may be from uncertainty associated with the sample flow rate. 

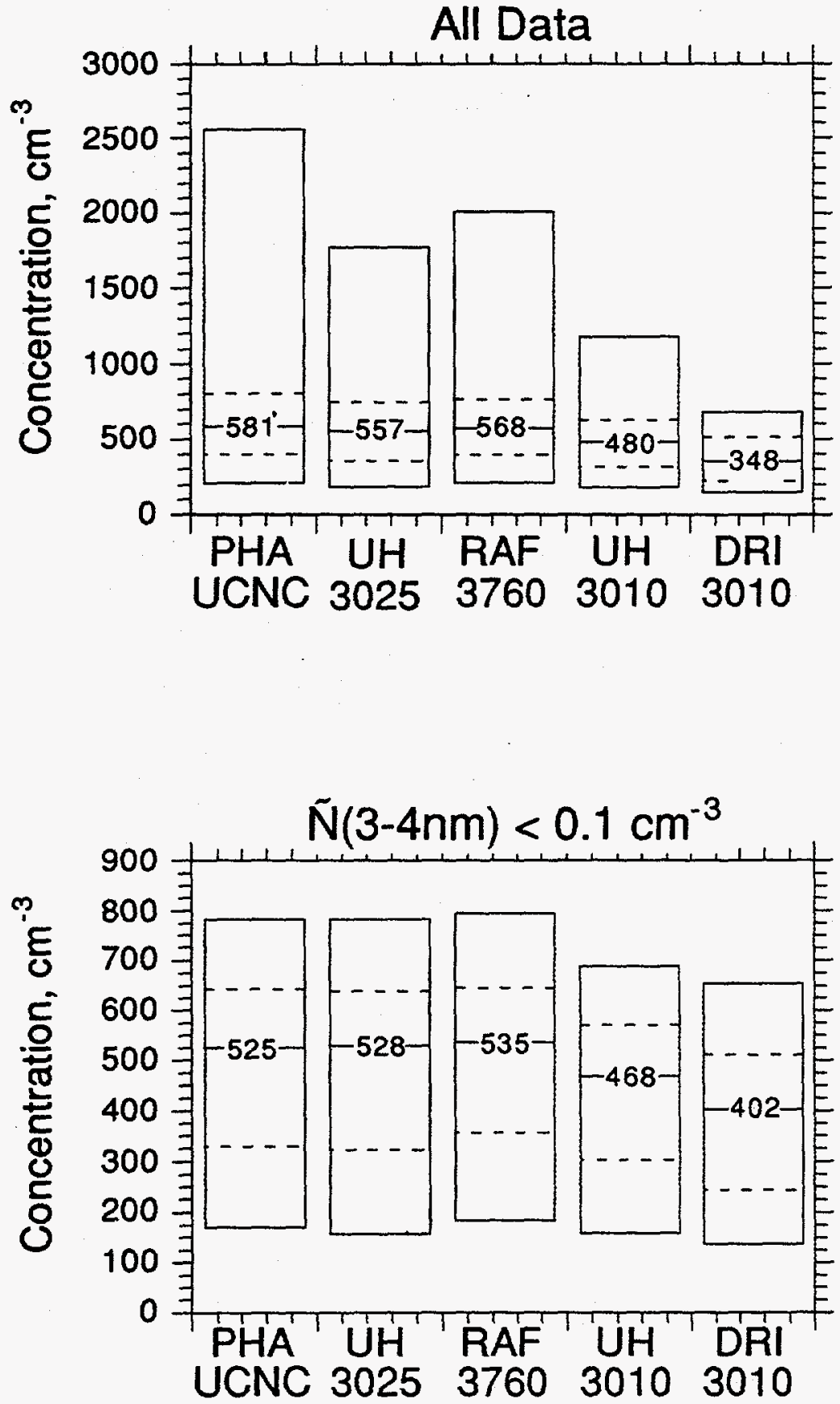

Figure 3: Percentile plots for C-130 CNC's based on measurements for flights 16 , $17,21,22$, and 27 . For each CNC, the bottom and top of the box represents $5 \%$ and $95 \%$ of the data, respectively. The dotted lines represent $25 \%$ and $75 \%$ of the data and the center line the median particle concentration.
Figure 4: Same as Figure 3 except only data during conditions of practically zero nanoparticle concentrations is considered. At these times, differences in $\mathrm{CNC}$ nanoparticle detection efficiencies will not influence the comparison. 


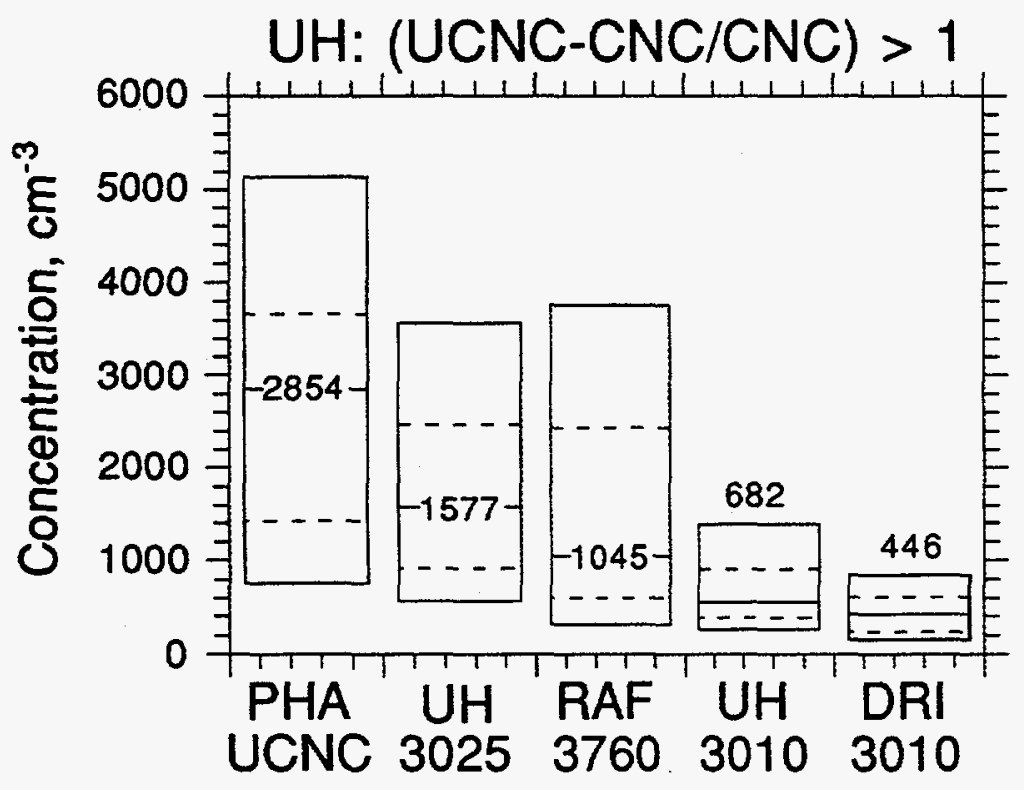

Figure 5: Same as Figure 3 except only periods of high nanoparticle $(3-10 \mathrm{~nm})$ concentrations are considered. These are periods when nanoparticle concentrations were higher than the concentration of particles larger than $\sim 10 \mathrm{~nm}$ diameter.

\section{Intercomparison of C-130 with Macquarie Island, Cape Grim and R/V Discoverer}

Tables B1 through B5, in Appendix B, summarize the CNC measurements, sample locations, temperatures and relative humidities recorded during the various platform intercomparisons. The Discoverer and C-130 were intercomparied during three separate flights. For the second Disco./C-130 intercomparison flight, two passes were made at different altitudes. These data were analyzed separately. The third Disco./C-130 intercomparison flight was not analyzed due to rain at the time of the measurements. The Macquarie Island intercomparison consisted of only a brief flyby of the ground-based station whereas more extensive flybys of Cape Grim were made during two separate flights.

Since the periods for these intercomparisons were relatively brief, statistical analysis was limited and the findings should be viewed with some degree of skepticism. Table 3 summarizes the findings. For each comparison, the average percent difference of the ship or ground based measurement to the RAF $3760 \mathrm{CNC}$ is calculated. The RAF $3760 \mathrm{CNC}$ was chosen since it was fairly representative of the aircraft $\mathrm{CNC}$ measurements. Table 3 shows that the R/V Discoverer UCNC recorded generally lower particle concentrations than the C-130. Cape Grim and C-130 $\mathrm{CNC}$ measurements were fairly close and Macquarie Island measurements were slightly lower than the aircraft measurements. 
Table 3: Average percent difference of ship and ground-based UCNC's and CNC's with the

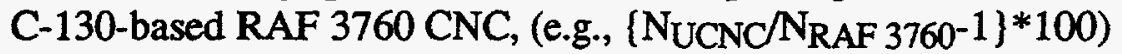

\begin{tabular}{lcc}
\hline \multicolumn{1}{c}{ Station } & $\begin{array}{c}\text { Station UCNC } \\
\text { \% Difference } \\
\text { (NUCNC/NRAF 3760-1)*100 }\end{array}$ & $\begin{array}{c}\text { Station CNC } \\
\text { \% Difference } \\
\text { (NCNC/NRAF 3760-1)*100 }\end{array}$ \\
\hline R/V Disco. \#1 & -20 & - \\
R/V Disco. \#2a & -13 & - \\
R/V Disco. \#2b & -22 & - \\
Cape Grim \#1 & +2.5 & +1.5 \\
Cape Grim \#2 & +3.1 & +5.2 \\
Macquarie Is. & -10 & -7 \\
\hline
\end{tabular}

\section{References}

Wiedensohler, A., D. Orsini, D. S. Covert, D. Coffmann, W. Cantrell, H. Halvlicek, F. J. Brechtel, L. M. Russell, R. J. Weber, J. Gras, J. G. Hudson, M. Litchy, Intercomparison study of the size-dependent counting efficiency of 26 condensation particle counters, Aerosol Sci. Tech., in press, 1997.

\section{Appendix A: Acronyms and Descriptions of CNC's}

$\mathrm{D}_{\mathrm{p}}$ :

$\mathrm{CN}$ :

CNC:

UCNC:

TSI:

3025, 3760, and 3010:

Cape Grim UCNC:

Cape Grim CNC:

DRI 3010:

Macquarie Is. UCNC:

Macquarie Is. CNC:

RAF 3760:

R/V Discoverer UCNC:

UM PHA UCNC:

UH 3025:

UH 3010:
Particle Diameter

Condensation Nucleus

Condensation Nucleus Counter

Ultrafine Condensation Nucleus Counter

Thermo-Systems Inc., St. Paul MN.

TSI designations for their various CNC"s.

University of Washington TSI $3025 \mathrm{UCNC}, \mathrm{D}_{\mathrm{p} 50}=2.3 \mathrm{~nm}$ University of Washington TSI $3010 \mathrm{CNC}, \mathrm{D}_{\mathrm{p} 50}=12 \mathrm{~nm}$

Desert Research Institute (DRI), TSI $3010 \mathrm{CNC}, \mathrm{D}_{\mathrm{p} 50}=15 \mathrm{~nm}$.

Colorado State University TSI 3025 UCNC, $D_{p 50}=2.5 \mathrm{~nm}$

Colorado State University TSI $3010 \mathrm{CNC}, \mathrm{D}_{\mathrm{p} 50}=12 \mathrm{~nm}$

Research Aviation Facility (RAF) National Center for Atmospheric

Research (NCAR), TSI $3760 \mathrm{CNC}, \mathrm{D}_{\mathrm{p} 50}=15 \mathrm{~nm}$ nominally $\left(\mathrm{D}_{\mathrm{p} 50}\right.$

was not measured during comparison prior to ACE-1).

Pacific Marine Environmental Laboratory Research Vessel

Discoverer, TSI 3025 UCNC, $D_{\mathrm{p} 50}=2.5 \mathrm{~nm}$

University of Minnesota (UM), UCNC with Pulse Height Analysis (PHA), $\mathrm{D}_{\mathrm{p} 50}=2.5 \mathrm{~nm}$.

University of Hawaii (UH), TSI 3025 UCNC, $D_{\mathrm{p} 50}=2.4 \mathrm{~nm}$.

University of Hawaii (UH), TSI $3010 \mathrm{CNC}, \mathrm{D}_{\mathrm{p} 50}=15 \mathrm{~nm}$. 


\section{Appendix B: Comparisons of Ship and Ground-Based CN Measurements with the C-130 Aircraft Measurements}

Table B1: Discoverer/ C-130 Comparison \#1

Flight 15, 25 Nov. 1995 (Julian day 329)

Time period (UTC): 1:00:00 - 1:30:00 Disco; 1:10:00 - 1:14:00 C-130

\begin{tabular}{|c|c|c|c|c|}
\hline & \multicolumn{2}{|c|}{ DISCO. } & \multicolumn{2}{|c|}{$\mathrm{C}-130$} \\
\hline Measurement & Mean & Range & Mean & Range \\
\hline UCNC, $\mathrm{cm}^{-3}$ & 349 & $\overline{332-368}$ & $\begin{array}{l}444 \mathrm{UM} \\
434 \mathrm{UH}\end{array}$ & $\begin{array}{l}23-504 \mathrm{UM} \\
411-467 \mathrm{UH}\end{array}$ \\
\hline $\mathrm{CNC}, \mathrm{cm}^{-3}$ & - & - & $\begin{array}{c}327 \mathrm{DRI} \\
393 \mathrm{UH} \\
\text { 434 RAF }\end{array}$ & $\begin{array}{l}17-341 \mathrm{DRI} \\
375-413 \mathrm{UH} \\
418-495 \mathrm{RAF}\end{array}$ \\
\hline & & & & \\
\hline Altitude, $\mathrm{m}$ & - & - & 48 & $31-114$ \\
\hline Latitude, deg. S & - & $47.30-47.385$ & - & $47.488-47.646$ \\
\hline Longitude, deg. E & - & $144.79-144.87$ & - & $145.07-145.20$ \\
\hline $\mathrm{T},{ }^{\circ} \mathrm{C}$ & 8.7 & - & 8.4 & $7.8-8.6$ \\
\hline $\mathrm{RH}, \%$ & 81 & - & 74 & $71-76$ \\
\hline
\end{tabular}

UM University of Minnesota; UH University of Hawaii; DRI Desert Research Institute;

RAF NCAR Research Aviation Facility

Table B2: Discoverer/ C-130 Comparison \#2

Flight 22, 5 Dec. 1995 (Julian day 339)

Pass a) Time period (UTC): 4:34:00 - 4:37:00

\begin{tabular}{|l|c|c|c|c|}
\cline { 2 - 5 } \multicolumn{1}{c|}{} & \multicolumn{2}{c|}{ DISCO. } & \multicolumn{2}{c|}{ C-130 } \\
\hline \multicolumn{1}{c|}{ Measurement } & Mean & Range & Mean & Range \\
\hline \hline UCNC, cm ${ }^{-3}$ & 578 & $546-640$ & $739 \mathrm{UM}$ & $639-865 \mathrm{UM}$ \\
& & & $670 \mathrm{UH}$ & $631-728 \mathrm{UH}$ \\
\hline $\mathrm{CNC}, \mathrm{cm}^{-3}$ & - & - & $450 \mathrm{DRI}$ & $304-483 \mathrm{DRI}$ \\
& & & $587 \mathrm{UH}$ & $552-627 \mathrm{UH}$ \\
& & & $662 \mathrm{RAF}$ & $636-708 \mathrm{RAF}$ \\
\hline & & & & \\
\hline Altitude, m & - & - & - & $28-50$ \\
\hline Latitude, deg. S & 41.343 & - & - & $41.339-41.466$ \\
\hline Longitude, deg. E & 139.06 & - & - & $138.95-139.06$ \\
\hline $\mathrm{T},{ }^{\circ} \mathrm{C}$ & 11.2 & - & 11.4 & $11.3-11.5$ \\
\hline $\mathrm{RH}, \%$ & 54 & - & 56 & $54-57$ \\
\hline
\end{tabular}

Pass b) Time period (UTC): 5:39:00 - 5:41:00

\begin{tabular}{|c|c|c|c|c|}
\hline & \multicolumn{2}{|c|}{ DISCO. } & \multicolumn{2}{|c|}{$C-130$} \\
\hline Measurement & Mean & Range & Mean & Range \\
\hline $\mathrm{UCNC}, \mathrm{cm}^{-3}$ & 518 & $513-521$ & $\begin{array}{l}704 \mathrm{UM} \\
670 \mathrm{UH}\end{array}$ & $\begin{array}{l}667-760 \mathrm{UM} \\
645-734 \mathrm{UH}\end{array}$ \\
\hline $\mathrm{CNC}, \mathrm{cm}^{-3}$ & - & - & $\begin{array}{l}540 \text { DRI } \\
593 \mathrm{UH} \\
667 \mathrm{RAF}\end{array}$ & $\begin{array}{l}\text { 501-681 DRI } \\
570-630 \mathrm{UH} \\
654-739 \mathrm{RAF}\end{array}$ \\
\hline & & & & \\
\hline Altitude, $\mathrm{m}$ & - & - & 158 & $155-160$ \\
\hline Latitude, deg. S & 41.382 & - & - & $41.260-41.359$ \\
\hline Longitude, deg. E & 138.992 & $=$ & - & $139.11-139.15$ \\
\hline $\mathrm{T},{ }^{\circ} \mathrm{C}$ & 11.1 & - & 10.4 & $10.3-10.4$ \\
\hline RH,\% & 58 & & 56 & $56-57$ \\
\hline
\end{tabular}


Table B3: Cape Grim/ C-130 CN Comparison \#1

Flight 14, 24 Nov. 1995 (Julian day 328)

Time period (UTC): 1:55:00 - 1:58:00

\begin{tabular}{|c|c|c|c|c|}
\hline & \multicolumn{2}{|c|}{ Cape Grim } & \multicolumn{2}{|c|}{$C-130$} \\
\hline Measurement & Mean & Range & Mean & Range \\
\hline $\mathrm{UCNC}, \mathrm{cm}^{-3}$ & 491 & $467-515$ & $\begin{array}{l}501 \mathrm{UM} \\
471 \mathrm{UH}\end{array}$ & $\begin{array}{l}454-533 \mathrm{UM} \\
407-556 \mathrm{UH}\end{array}$ \\
\hline $\mathrm{CNC}, \mathrm{cm}^{-3}$ & 486 & $464-508$ & $\begin{array}{l}373 \mathrm{DRI} \\
427 \mathrm{UH} \\
479 \mathrm{RAF} \\
\end{array}$ & $\begin{array}{c}355-400 \text { DRI } \\
392-469 \text { UH } \\
431-721 \mathrm{RAF} \\
\end{array}$ \\
\hline & & & & \\
\hline Altitude, $\mathrm{m}$ & 94+mast & - & 46 & $37-62$ \\
\hline Latitude, deg. S & 40.6822 & - & - & $40.621-40.673$ \\
\hline Longitude, deg. E & 144.688 & - & - & $144.48-144.67$ \\
\hline $\mathrm{T},{ }^{\circ} \mathrm{C}$ & 10.2 & - & 10.9 & $10.4-11.2$ \\
\hline$\overline{\mathrm{RH}}, \%$ & 68 & $67-70$ & 58 & $53-67$ \\
\hline
\end{tabular}

Table B4: Cape Grim/ C-130 CN Comparison \#2

Flight 27, 10 Dec. 1995 (Julian day 344)

Time period (UTC): 23:33:00 - 23:36:00

\begin{tabular}{|c|c|c|c|c|}
\hline & \multicolumn{2}{|c|}{ Cape Grim } & \multicolumn{2}{|c|}{$C-130$} \\
\hline Measurement & Mean & Range & Mean & Range \\
\hline $\mathrm{UCNC}, \mathrm{cm}^{-3}$ & 1047 & - & $\begin{array}{l}1160 \text { UM } \\
1019 \text { UH }\end{array}$ & $\begin{array}{l}1087-1232 \mathrm{UM} \\
933-1135 \mathrm{UH}\end{array}$ \\
\hline $\mathrm{CNC}, \mathrm{cm}^{-3}$ & 1069 & - & $\begin{array}{c}768 \mathrm{DRI} \\
898 \mathrm{UH} \\
1016 \mathrm{RAF}\end{array}$ & $\begin{array}{c}\text { 673-843 DRI } \\
\text { 823-986 UH } \\
941-1102 \mathrm{RAF}\end{array}$ \\
\hline & & 㕈 & & 20 \\
\hline Altitude, $\mathrm{m}$ & $94+$ mast & - & 102 & $90-116$ \\
\hline Latitude, deg. S & 40.6822 & - & - & $40.647-40.653$ \\
\hline Longitude, deg. E & 144.688 & - & - & $144.56-144.76$ \\
\hline $\mathrm{T},{ }^{\circ} \mathrm{C}$ & 9.4 & - & 9.6 & $9.4-9.8$ \\
\hline $\mathrm{RH}, \%$ & 65 & $63-66$ & 54 & $52-56$ \\
\hline
\end{tabular}

Table B5: Macquarie Island/ C-130 CN Comparison

Flight 16, 27 Nov. 1995 (Julian day 331)

Time period (UTC): 3:05:00 - 3:15:00 Macquarie Island; 3:11:00 - 3:12:00 C-130.

\begin{tabular}{|c|c|c|c|c|}
\hline & \multicolumn{2}{|c|}{ Macquarie Is. } & \multicolumn{2}{|c|}{$C-130$} \\
\hline Measurement & Mean & Range & Mean & Range \\
\hline UCNC, $\mathrm{cm}^{-3}$ & $\overline{501}$ & $498-504$ & $\begin{array}{l}558 \mathrm{UM} \\
570 \mathrm{UH}\end{array}$ & $\begin{array}{c}-\mathrm{UM} \\
540-585 \mathrm{UH}\end{array}$ \\
\hline $\mathrm{CNC}, \mathrm{cm}^{-3}$ & 519 & $515-524$ & $\begin{array}{c}\text { - DRI } \\
521 \mathrm{UH} \\
558 \mathrm{RAF}\end{array}$ & $\begin{array}{c}\text { - DRI } \\
517-524 \mathrm{UH} \\
547-568 \mathrm{RAF}\end{array}$ \\
\hline & & & & 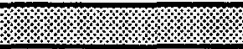 \\
\hline Altitude, $\mathrm{m}$ & 5 & - & 67 & $41-90$ \\
\hline Latitude, deg. S & 54.50 & - & - & $54.43-54.47$ \\
\hline Longitude, deg. E & 158.95 & $=$ & - & $158.97-159.03$ \\
\hline $\mathrm{T},{ }^{\circ} \mathrm{C}$ & 6.3 & - & 3.8 & $3.5-4.2$ \\
\hline $\mathrm{RH}, \%$ & 47 & - & 59 & $56-67$ \\
\hline
\end{tabular}

